\title{
Evaluasi Kinerja Program Pengentasan Kemiskinan (Studi Program Anti Kemiskinan Bidang Pertanian di Kabupaten Tuban)
}

\author{
Soni Kurniawan ${ }^{1}$, Andy Fefta Wijaya ${ }^{1.2}$, Tjahjanulin Domai ${ }^{1.2}$ \\ ${ }^{1}$ Program Magister Ilmu Administrasi Publik, Fakultas IImu Administrasi, Universitas Brawijaya \\ ${ }^{2}$ Fakultas Ilmu Administrasi, Universitas Brawijaya
}

\begin{abstract}
Abstrak
Program Anti Kemiskinan (Anti Poverty Program) Bidang Pertanian merupakan program penanggulangan kemiskinan dengan menggunakan pendekatan pemberdayaan masyarakat. Konsep dasar program ini adalah pemberdayaan usaha ekonomi produkif Kelompok Masyarakat Miskin yang difasilitasi pendampingan dan Mitra Usaha sebagai penampung/pembeli hasil produksi dari Pokmas (Pasar). Pokmas mendapatkan bantuan yang bersifat hibah, selanjutnya menjadi aset Pokmas untuk dimanfaatkan oleh anggota dan diwajibkan untuk melakukan perguliran dengan mekanisme sesuai dengan kesepakatan anggota. Penelitian ini merupakan penelitian kualitatif melalui observasi, wawancara, dokumentasi. Berdasarkan hasil penelitian memperlihatkan, bahwa Program Anti Kemiskinan (Anti Poverty Program) Bidang Pertanian secara signifikan belum mampu menurunkan jumlah penduduk miskin. Pada kinerja input SDM Pokmas dan Tenaga Pendamping Pokmas dinilai masih kurang memadai. Rata-rata pendidikan anggota Pokmas sangat rendah, dimana hampir 81,28\% sampai dengan lulusan SD dengan tingkat kepemilikan lahan pertanian sawah sebanyak 71,02 \% kurang dari 0,5 hektar. Dilihat dari indikator kinerja proses, tahap pelaksanaan Musyawarah Desa (Musdes) perencanaan dan realisasi pencairan bantuan masih kurang optimal. Realisasi bantuan sarana dan prasarana produksi pertanian khususnya melalui APBD Provinsi Jawa Timur, tidak sesuai dengan jadwal yang telah ditentukan (pada saat awal musim tanam). Pada kinerja output dan outcome, secara umum sudah sesuai dengan tujuan dan sasaran. Secara kualitas, Program Anti Kemiskinan (Anti Poverty Program) Bidang Pertanian dapat menangani Gakin sebanyak 593 orang, meningkatkan pendapatan anggota Pokmas rata-rata sebesar 16,16\% dan penyerapan tenaga kerja sebanyak 625 orang.
\end{abstract}

Kata kunci: Evaluasi, Evaluasi Kinerja, Kemiskinan, Kinerja

\begin{abstract}
Anti Poverty Program in Agriculture sector is a program to overcome poverty by using community development approach. The basic concept of this program is the empowerment of productive economy group that consists of the poor. This program is facilitated by the assistants and business partners as reservoirs or production buyers of Pokmas. Pokmas receives a grant from the program. This grant, then, becomes an asset to be used by members of Pokmas in carrying out business activities and in implementing of revolving fund accordance with the agreement of group members. This study is a qualitative research through observation, interviews and documentation. The results of this study describe the Anti Poverty Program has not been able to significantly decrease the amount of the poor. On the performance indicator of input is dealing with the low human resources of Pokmas and the inadequate of assistants' role. The average of Pokmas has a low education, approximately $81.28 \%$ were primary school graduates with ownership of agricultural land less than 0.5 acres of paddy field is $71.02 \%$. On the performance indicator of process describes the planning process and implementation are not functioning properly. The realization stage of agricultural production infrastructure through APBD of East Java Province, is often not accordance with the schedule (at the beginning of the growing season). On the performance indicator of output and outcome, in general is accordance with the purposes and objectives of Anti Poverty Program Guidelines. In quality of Anti Poverty Programs can handle as many as 593 people of Gakin, increases the revenue of Pokmas in the amount of $16.16 \%$ and the employment of 625 people.
\end{abstract}

Keyword: Evaluation, Performance, Performance Evaluation, Poverty

\section{PENDAHULUAN}

Pada dasarnya isu tentang kemiskinan dan kesenjangan ekonomi, baik antar golongan masyarakat maupun antar wilayah menjadi persoalan mendasar bagi bangsa Indonesia. Berbagai program dalam pembangunan telah dilaksanakan baik di tingkat Pusat, Regional,

Corresponding Address:

Soni Kurniawan

Email : Sonitarunakurniaone@yahoo.co.id maupun Daerah, akan tetapi hasil dari penurunan tingkat kemiskinan masih jauh dari harapan.

Esensi dari sebuah program pengentasan kemiskinan adalah membantu masyarakat miskin agar memiliki kemampuan berusaha dan mandiri dari segi ekonomi, sehingga program kemiskinan seharusnya bersifat komprehensif dan ditujukan

Alamat : Jalan Mutiara N-8 Bukit Karang, Tuban, Jawa Timur 
langsung ke akar permasalahan dari kemiskinan [1].

Dalam publikasi profil kemiskinan di Jawa Timur pada Bulan Maret 2012, penduduk miskin di Jawa Timur sebanyak 5,071 juta. Secara aggregat sebanyak 67,84 persen atau sekitar 3,44 juta penduduk diantaranya ada di daerah perdesaan [2]. Selanjutnya, apabila mengacu hasil Pendataan Program Perlindungan Sosial PPLS 2011 jumlah keluarga miskin (Gakin) di Kabupaten Tuban mencapai 122.120 RTM dengan tingkat kemiskinan mencapai $18,78 \%$ dari jumlah penduduk yang ada. Dari data tersebut, jumlah penduduk miskin (Gakin) yang berada di lokasi sasaran sebesar 1.463 RTM atau 5.570 jiwa. Sebagian besar mata pencaharian penduduknya sebagai petani sebesar 7.849 dan buruh tani 4.273 [3].

Pada umumnya tingkat pengetahuan dan ketrampilan petani masih rendah, permodalan yang terbatas dengan luas lahan yang dimiliki ratarata $<0,5$ hektar. Hal ini menyebabkan kegiatan usaha tani yang mereka jalankan kurang efisien, sumberdaya tidak termanfaatkan secara optimal dan produktivitas usaha taninya rendah.

Persoalan kemiskinan dapat dipahami lebih jauh dengan memunculkan beberapa kosakata standar dalam kajian kemiskinan Friedmann [4] sebagai berikut:

1. Poverty line, tingkat konsumsi rumah tangga minimum yang dapat diterima secara sosial dan dihitung oleh ahli statistik kesejahteraan sebagai persediaan kalori dan protein utama yang paling murah berdasarkan income yang dua pertiganya digunakan untuk "keranjang pangan".

2. Absolute and relative poverty, kemiskinan yang jatuh dibawah standar konsumsi minimum yang tergantung pada kebaikan (karitas/amal). Sedangkan kemiskinan relatif sering dianggap sebagai kesenjangan antara kelompok miskin dan kelompok non miskin berdasarkan income relatif.

3. Deserving poor, kaum miskin yang mau peduli dengan harapan orang-orang nonmiskin, bersih, bertanggungjawab, mau menerima pekerjaan apa saja demi memperoleh upah yang ditawarkan.

4. Target population, kelompok orang tertentu yang dijadikan sebagai objek, kebijakan serta program pemerintah, berupa rumah tangga yang dikepalai perempuan, anakanak, buruh tani yang tak punya lahan, petani tradisional kecil, korban perang dan wabah, serta penghuni kampung kumuh perkotaan.

Penanganan kemiskinan menjadi salah satu agenda prioritas dalam Rencana Pembangunan Jangka Menengah Daerah (RPJMD) Kabupaten Tuban Tahun 2011 - 2016 dengan berupaya menurunkan angka kemiskinan pada Tahun 2016 menjadi 15,26 \%. Melihat kondisi tersebut, diperlukan perhatian khusus dan upaya terus menerus dalam penanggulangan kemiskinan. Salah satu program prioritas penanggulangan kemiskinan yaitu dengan mendukung kegiatan Pemerintah Provinsi Jawa Timur melalui alokasi dana pendamping (cost sharing) Program Anti Kemiskinan (Anti Poverty Program). Konsep dasar adalah pemberdayaan usaha ekonomi produktif Kelompok Masyarakat Miskin. Kelompok Masyarakat (Pokmas) mendapat bantuan sarana dan prasarana Produksi dari Pemerintah yang bersifat hibah selanjutnya menjadi aset Pokmas untuk dimanfaatkan oleh anggota dan diwajibkan untuk melakukan perguliran dengan mekanisme sesuai kesepakatan anggota [5].

Dalam kurun waktu pelaksanaan program Anti Kemiskinan (Anti Poverty Program) Bidang Pertanian selama 5 tahun (2008 - 2012), seharusnya diikuti dengan peningkatan kondisi sosial ekonomi masyarakat. Akan tetapi pada kenyataanya masih ditemukan beberapa kelemahan dilapangan, antara lain:

1. Jumlah keluarga miskin di lokasi sasaran relatif banyak, yaitu sebesar 1.463 RTM atau 5.570 jiwa

2. Jumlah penduduk angkatan kerja (10 tahun ke atas) Tahun 2011, banyak didominasi oleh petani sebesar 7.849 dan buruh tani 4.273 orang

3. Tingkat pendidikan petani rendah dan permodalan yang terbatas

Berdasar uraian sebagaimana tersebut diatas, adanya Program Anti Kemiskinan (Anti Poverty Program) Bidang Pertanian diharapkan dapat mengembangkan kemampuan dan peluang usaha dalam rangka peningkatan pendapatan dan kesejahteraan bagi kelompok masyarakat miskin. Untuk itu perlu dilakukan penilaian atau evaluasi kinerja sejauh mana pencapaian target kinerja program sesuai dengan sasaran dan tujuan.

Evaluasi Kinerja merupakan kegiatan untuk menilai atau melihat keberhasilan dan kegagalan satuan organisasi/kerja dalam melaksanakan tugas dan fungsi yang dibebankan kepadanya. Dalam melakukan evaluasi kinerja, hasilnya agar dikaitkan dengan sumberdaya (input) yang berada dibawah wewenangnya seperti SDM, 
dana/keuangan, sarana-prasarana, metode kerja dan lain-lain yang berkaitan [6].

Selanjutnya dalam pelaksanaan evaluasi kinerja dapat dilakukan dengan mengevaluasi kegiatan dan sasaran, bisa juga mengevaluasi program dan kebijakan yang telah ditetapkan atau secara menyeluruh sehingga akhirnya dapat disimpulkan kinerja organisasi [7].

1. Evaluasi Kinerja Kegiatan dan sasaran. Evaluasi terhadap kegiatan instansi adalah bentuk paling kecil dari evaluasi kinerja organisasi. Seluruh atau sebagian kegiatan dapat dievaluasi menurut prioritas manajemen instansi. Tingkat pentingnya evaluasi sangat ditentukan oleh tingkat pentingnya kegiatan itu sendiri. Jika kegiatan tersebut merupakan kegiatan pokok atau kegiatan utama yang merupakan ciri organisasi instansi dalam pelayanan kepada masyarakat atau kegiatan yang cukup dominan dalam rangka menjalankan misi instansi, maka dapat dikatakan bahwa kegiatan itu adalah penting.

Evaluasi kinerja kegiatan dapat dilakukan dengan dua pendekatan, yaitu input-prosesoutput dan input dan output.

Pendekatan pertama akan dapat memberikan rekomendasi atau feed back tentang berbagai hal baik peningkatan hasil (output) maupun prosesnya. Pendekatan yang kedua masih menyisakan pertanyaan tentang bagaimana caranya meningkatkan kinerja dengan memperbaiki proses pelayanan/produksi yang dilakukan.

Bagi instansi pemerintah kegiatan evaluasi dengan pendekatan yang pertama dilakukan secara lebih sering dan teratur (per triwulan/semester) disesuaikan dengan pola monitoring kinerja secara reguler. Sedangkan pendekatan kedua dilakukan dalam waktu yang agak lama (setahun atau 2 tahun).

Oleh karena itu evaluasi yang dilakukan secara reguler sangat mengandalkan sistem pengumpulan data internal yang digunakan dalam memantau (monitoring) kegiatan.

2. Evaluasi Program dan Kebijakan.

Evaluasi program cenderung dilakukan untuk mencari jawaban akan outcomes yang dihasilkan, sedangkan evaluasi kebijakan mungkin saja mulai outcomes hingga dampak (impacts) yang terjadi.

\section{METODOLOGI PENELITIAN}

Jenis penelitian yang digunakan di dalam kajian ini adalah penelitian kualitatif, mengingat penelitian ini menghasilkan gambaran (deskripsi) mengenai hal-hal yang berkaitan dengan Program Anti Kemiskinan (Anti Poverty Program) Bidang Pertanian dengan terjun langsung ke lokasi penelitian untuk meneliti kondisi riil di lapangan. Sebagai landasan teori dalam memahami pendekatan kualitatif berdasarkan pendapat Bogdan dan Taylor (Moleong) [8] yang mendefinisikan "metode kualitatif" sebagai prosedur penelitian yang menghasilkan data deskriptif berupa kata-kata tertulis atau lisan dari orang-orang dan perilaku yang dapat diamati.

\section{Metode Pengumpulan Data}

Dalam rangka pengumpulan data dalam penelitian ini, peneliti menggunakan tiga teknik pengumpulan data sebagai berikut : wawancara secara mendalam (Indepth Interview), dokumentasi serta observasi. Untuk menganalisis data hasil penelitian yang diperoleh, peneliti menggunakan teknik menggunakan analisis data dari Miles dan Huberman [9], terdiri dari reduksi data, penyajian data, dan penarikan kesimpulan atau verifikasi. Akan tetapi sebelum dilakukan 3 (tiga) analisa tersebut, dilakukan kegiatan pendahuluan yaitu pengumpulan data.

\section{HASIL DAN PEMBAHASAN}

Pelaksanaan Program Anti Kemiskinan (Anti Poverty Program) Bidang Pertanian di Kabupaten Tuban

Program Anti Kemiskinan (Anti Poverty Program) Bidang Pertanian merupakan program penanggulangan kemiskinan dengan menggunakan pendekatan pemberdayaan masyarakat yang tidak hanya pada pelaksanaan program saja, tetapi masyarakat sebagai penerima bantuan dalam wadah kelompok diberikan keleluasaan dalam penentuan kegiatan mulai tahap perencanaan program sampai dengan pelestarian.

Pelaksanaan Program Anti Kemiskinan (Anti Poverty Program) Bidang Pertanian di Tingkat Kabupaten telah dibentuk Tim Koordinasi, Sekretariat Program dan Kelompok Kerja Kecamatan melalui Keputusan Bupati Tuban. Setiap organisasi selalu menggunakan manajemen dalam proses optimasi semua sumberdaya dalam pencapaian tujuan yang tel ah ditetapkan. Sejalan dengan pendapat Shafritz dan Russel [10] manajemen berkenaan dengan orang yang bertanggungjawab menjalankan suatu organisasi, dan proses menjalankan organisasi itu sendiri yaitu pemanfaatan sumberdaya (seperti orang dan mesin) untuk mencapai tujuan organisasi. 
Evaluasi Kinerja Program Anti Kemiskinan (Anti Poverty Program) Bidang Pertanian di Kabupaten Tuban)

Evaluasi kinerja program merupakan kegiatan lebih lanjut dari kegiatan pengukuran kinerja dan pengembangan indikator kinerja, oleh karena itu dalam melakukan evaluasi kinerja harus berpedoman pada ukuran-ukuran dan indikator yang telah disepakati dan ditetapkan bersama [6]. Evaluasi kinerja program merupakan suatu proses umpan balik atas kinerja masa lalu yang berguna untuk meningkatkan produktivitas dimasa datang, sebagai suatu proses yang berkelanjutan, evaluasi kinerja menyediakan informasi mengenai kinerja dalam hubungannya terhadap tujuan dan sasaran.

Evaluasi dilakukan untuk memberikan informasi beberapa hal terkait input, proses, output maupun outcome kegiatan apakah sesuai dengan sasaran yang telah diinginkan. Beberapa manfaat dari evaluasi kinerja program antara lain: a. Sebagai wacana pemahaman pola pembangunan berwawasan pemberdayaan masyarakat melalui Program Anti Kemiskinan (Anti Poverty Program) Bidang Pertanian. Keberhasilan program tidak hanya dilihat dari pelaksanaannya saja, akan tetapi dilihat dari tingkat partisipasi Pokmas mulai perencanaan, pelaksanaaan sampai dengan pelestarian.

b. Sebagai bahan masukan dalam penyusunan strategi dan kebijakan pembangunan yang ditujukan kepada masyarakat terutama yang berkaitan dengan penanggulangan kemiskinan.

Evaluasi kinerja kegiatan dapat dilakukan dengan dua pendekatan, yaitu input-prosesoutput dan input dan output [7]. Berkaitan dengan evaluasi kinerja terhadap Program Anti Kemiskinan (Anti Poverty Program) Bidang Pertanian di Kabupaten Tuban yang juga mengkaji proses pelaksanaan program, maka pendekatan yang digunakan yaitu input-proses-output sesuai dengan tujuan penelitian.

$$
\text { Lebih jauh }
$$

Mahsun

mengklasifikasikan beberapa jenis indikator kinerja, antara lain: indikator masukan, proses, keluaran, hasil, manfaat, dan dampak. Penjelasan singkat tentang jenis indikator tersebut adalah sebagai berikut:

1. Indikator masukan (input) mencerminkan segala sesuatu yang dibutuhkan agar pelaksanaan kegiatan dapat berjalan sesuai yang diharapkan guna menghasilkan keluaran. Indikator ini mengukur jumlah sumber daya, seperti anggaran (dana), SDM, peralatan, material, dan masukan lain.

2. Indikator proses (process). Dalam indikator proses, organisasi harus merumuskan ukuran kegiatan, baik dari segi kecepatan, ketepatan maupun tingkat akurasi pelaksanaan kegiatan tersebut.

3. Indikator keluaran (output) adalah sesuatu yang diharapkan langsung dan dapat dicapai dari suatu kegiatan yang dapat berupa fisik maupun non fisik.

4. Indikator hasil (outcomes) adalah segala sesuatu yang mencerminkan berfungsinya keluaran kegiatan pada jangka menengah (efek langsung).

5. Indikator manfaat (benefit) adalah sesuatu yang terkait dengan tujuan akhir dari pelaksanaan kegiatan. Indikator manfaat menggambarkan manfaat yang diperoleh dari indikator hasil. Manfaat tersebut baru nampak setelah beberapa waktu kemudian, khususnya dalam jangka menengah dan panjang.

6. Indikator dampak (impact) adalah pengaruh yang ditumbuhkan baik positif maupun negatif.

Pada penelitian ini dibahas indikator kinerja Program Anti Kemiskinan (Anti Poverty Program) Bidang Pertanian di Kabupaten Tuban sebagai berikut:

\section{Kinerja Input}

Merupakan segala sesuatu yang dibutuhkan agar pelaksanaan kegiatan dapat berjalan untuk menghasilkan keluaran. Indikator ini mengukur jumlah sumber daya, seperti anggaran (dana), sumber daya manusia, peralatan, material, dan masukan lain, yang dipergunakan untuk melaksanakan kegiatan [11]. Kinerja input Program Anti Kemiskinan (Anti Poverty Program) Bidang Pertanian di Kabupaten Tuban terdiri dari :

\section{Input SDM \\ Pengelola Program}

Pengelolaan Program Anti Kemiskinan (Anti Poverty Program) Bidang Pertanian Tingkat Kabupaten dibentuk Tim Koordinasi Tingkat Kabupaten, meliputi : Bappeda Kabupaten sebagai Ketua Tim Koordinasi sekaligus sebagai Sekretariat program, sedangkan anggota Tim Koordinasi Tingkat Kabupaten terdiri dari SKPD terkait dan Kelompok Kerja Kecamatan.

Pada pelaksanaan Program Anti Kemiskinan (Anti Poverty Program) Bidang Pertanian di Kabupaten Tuban, telah dibentuk 
Keputusan Bupati Tuban tentang Tim Koordinasi, Sekretariat Program dan Kelompok Kerja Kecamatan Program Anti Kemiskinan (Anti Poverty Program) Bidang Pertanian.

Kelompok Masyarakat (Pokmas) Penerima Program Anti Kemiskinan (Anti Poverty Program) Bidang Pertanian.

Secara lokalistik penelitian ini dilakukan di 7 (tujuh) Desa penerima bantuan, mulai Tahun 2008 sampai dengan Tahun 2012. Adapun lokasi tersebut meliputi Desa Ngadipuro, Patihan, Bunut, Banjar, Kedungharjo, Tegalsari dan Kujung Kecamatan Widang.

Dari ketujuh lokasi tersebut terdapat 593 anggota Pokmas penerima bantuan program, dengan jenis kelamin laki-laki sebanyak 489 orang atau $82,46 \%$, dan perempuan sebanyak 104 orang atau $17,54 \%$. Selain itu dari hasil penelitian ini ditemukan beberapa hal sebagai berikut : (a) Usia anggota Pokmas penerima program sebagian terklasifikasi pada usia produktif yaitu sebanyak 501 orang atau 84,49\%. (b) Rata-rata pendidikan anggota Pokmas sangat rendah dimana hampir 81,28 \% sampai dengan lulusan SD. Persoalan lain yang mendasar adalah tidak dimilikinya jenis ketrampilan tertentu selain ketrampilan di bidang pertanian (c) Mayoritas kelompok masyarakat memiliki pekerjaan pokok sebagai petani $67,45 \%$ dan buruh tani $24,28 \%$, pedagang $1,35 \%$ dan lainnya 6,91 \%. Banyaknya masyarakat yang memiiki pekerjaan pokok sebagai petani atau buruh tani mengindikasikan bahwa sektor pertanian merupakan sumber penyangga ekonomi yang utama bagi keluarganya. Akan tetapi usaha pertanian yang ditekuni tidak didukung dengan tingkat kepemilikan lahan pertanian sawah yang memadai. Rata-rata anggota Pokmas memilik lahan pertanian sangat terbatas, yaitu sebanyak 72,01 \% lahan yang dikelola < 0,5 hektar, sehingga mengakibatkan usaha pertanian sampai saat ini masih banyak didominasi oleh usaha skala kecil dengan modal terbatas (d) Kondisi pendapatan Pokmas untuk memenuhi kebutuhan sehari-hari, sebagian besar $(45,70 \%)$ dalam kondisi pas-pasan dan hampir $37,10 \%$ relatif kurang.

\section{Tenaga Pendampingan}

Peran Konsultan Teknis Kecamatan dan Pendamping Kelompok Masyarakat ternyata cukup signifikan. Tugas tenaga pendamping yaitu memberikan dan mentransformasikan Program Anti Kemiskinan (Anti Poverty Program) Bidang Pertanian, mensosialisasikan program, serta memberikan bimbingan dalam penyusunan program.

Dari hasil penelitian dan wawancara dengan beberapa informan, dalam pelaksanaan pendampingan sebagaimana tugas tersebut diatas, belum berjalan dengan baik, hal ini disebabkan :

- Kemampuan, wawasan dan kualitas tenaga pendamping masih belum optimal

- Jumlah tenaga pendamping relatif terbatas.

\section{Input Biaya}

Program Anti Kemiskinan (Anti Poverty Program) Bidang Pertanian pendanaannya bersumber dari APBD Provinsi Jawa Timur dan APBD Kabupaten Tuban. APBD Provinsi Jawa Timur dipergunakan untuk fasilitasi paket bantuan/sarana produksi bagi Kelompok Masyarakat Keluarga Miskin (Pokmas Gakin), dana pembiayaan/pinjaman bagi Mitra Usaha, operasional Tim Provinsi dan Konsultan Manajemen Provinsi. Cost Sharing APBD Kabupaten dipergunakan untuk membiayai operasional Tim Koordinasi/Tim Teknis Kabupaten, Kelompok Kerja di Tingkat Kecamatan, biaya Musyawarah Desa, Konsultan Teknis Kecamatan, pendamping Kelompok Masyarakat, pembinaan untuk pelestarian serta pengembangan kegiatan.

Alokasi pendanaan yang telah dibantukan sejak Tahun 2008 sampai dengan Tahun 2012 sebesar Rp. 1.645.000.000,- terdiri dari : APBD Provinsi Jawa Timur sebesar Rp. 550.000.000,dan cost sharing APBD Kabupaten Tuban sebesar Rp. 1.095.000.000,-- sebagaimana Tabel 1 diatas. Rata-rata setiap anggota Pokmas menerima bantuan senilai Rp. 600.000,- (Enam Ratus Ribu Rupiah) sampai dengan Rp. 800.000,- (Delapan Ratus Ribu Rupiah). Berkaitan dengan jumlah alokasi pendanaan, dapat disampaikan bahwa anggaran yang ada masih sangat terbatas. Hal ini mengakibatkan jumlah masyarakat miskin yang tertangani dan jumlah alokasi dana bantuan untuk masing-masing Pokmas keluarga miskin masih sangat terbatas sehingga hasilnya kurang maksimal.

Tabel 1. Alokasi Dana Program Anti Kemiskinan (Anti Poverty Program) Bidang Pertanian di Kabupaten Tuban Tahun 2008 2012 
Sumber: Laporan Akhir Program Anti Kemiskinan Kabupaten Tuban Tahun 2012 [12]

\begin{tabular}{|c|c|c|c|c|c|c|c|}
\hline \multirow{3}{*}{ No. } & \multirow{3}{*}{ Desa } & \multirow{3}{*}{ Nama Pokmas } & \multirow{3}{*}{$\begin{array}{c}\text { Jumlah } \\
\text { Anggota } \\
\text { Pokmas } \\
\text { (RTM) }\end{array}$} & \multirow{3}{*}{$\begin{array}{c}\text { APBD } \\
\text { Provinsi }\end{array}$} & \multirow{2}{*}{\multicolumn{2}{|c|}{$\begin{array}{l}\text { Jumlah Dana ( Rp.) } \\
\text { APBD Kabupaten }\end{array}$}} & \multirow{3}{*}{$\begin{array}{c}\text { Jumlah APBD } \\
\text { Kabupaten }\end{array}$} \\
\hline & & & & & & & \\
\hline & & & & & $\begin{array}{l}\text { Bantuan } \\
\text { Keuangan }\end{array}$ & BOP & \\
\hline \multirow{3}{*}{1.} & \multirow{3}{*}{ Ngadipuro } & Sejahtera & 50 & 50.000 .000 & 20.000 .000 & \multirow{3}{*}{145.000 .000} & \multirow{3}{*}{210.000 .000} \\
\hline & & Mandiri & 50 & 50.000 .000 & 45.000 .000 & & \\
\hline & & Tunas Karya & 60 & 50.000 .000 & 20.000 .000 & & \\
\hline \multirow[t]{2}{*}{2} & Patihan & Sejahtera & 60 & 50.000 .000 & 20.000 .000 & \multirow{4}{*}{180.000 .000} & \multirow{4}{*}{260.000 .000} \\
\hline & & Mandiri & & & & & \\
\hline \multirow{2}{*}{3.} & \multirow{2}{*}{ Bunut } & Bangun Tani & 60 & 50.000 .000 & 20.000 .000 & & \\
\hline & & Tani Mulyo & 60 & 50.000 .000 & 20.000 .000 & & \\
\hline 4. & Banjar & Tani Maju & 53 & 50.000 .000 & 25.000 .000 & 200.000 .000 & 225.000 .000 \\
\hline \multirow{2}{*}{5.} & \multirow{2}{*}{ Kedungharjo } & Makmur Jaya & 50 & 50.000 .000 & 25.000 .000 & \multirow{2}{*}{200.000 .000} & \multirow{2}{*}{250.000 .000} \\
\hline & & Mekar Jaya & 50 & 50.000 .000 & 25.000 .000 & & \\
\hline 6. & Kujung & Ayem Tani & 50 & 50.000 .000 & 0 & \multirow{2}{*}{150.000 .000} & \multirow{2}{*}{150.000 .000} \\
\hline \multirow[t]{2}{*}{7.} & Tegalsari & Tanjung Sari & 50 & 50.000 .000 & 0 & & \\
\hline & $J U M$ & A $\mathrm{H}$ & 593 & 550.000 .000 & 220.000 .000 & 875.000 .000 & 1.095 .000 .000 \\
\hline
\end{tabular}

Dari pembahasan tersebut diatas dapat diuraikan bahwa kinerja input sangat dipengaruhi oleh aspek sumberdaya manusia dan biaya. Hal ini sesuai dengan pendapat Mahmudi ([13], input (masukan) adalah semua jenis sumber daya masukan yang digunakan dalam suatu proses tertentu untuk menghasilkan output. Input dibagi menjadi dua, yaitu input primer (kas) dan input sekunder (bahan baku, orang, infrastruktur dan barang modal. Input primer harus diubah menjadi input sekunder dalam proses menghasilkan output.

\section{Kinerja Proses}

Untuk menilai kinerja proses maka dapat dilihat pada pelaksanaan program dari tahapan perencanaan sampai dengan pengawasan yang kemudian dibandingkan dengan tujuan tiap kegiatan yang sesuai dengan Pedoman Umum Program Anti Kemiskinan (Anti Poverty Program) Kabupaten Tuban.

Sebagai salah satu bentuk perluasan aktivitas pengentasan kemiskinan, Program Anti Kemiskinan (Anti Poverty Program) Bidang Pertanian tidak hanya menitikberatkan pada kegiatan hasil akhir saja, namun lebih memperhatikan proses yang pada gilirannya diarahkan pada upaya memberdayakan kelompok masyarakat.

Hal ini sesuai dengan pendapat Makmur [14], proses internal dari suatu program merupakan salah satu syarat agar program mampu menimbulkan dampak yang diharapkan. Suatu proses merupakan sistem yang kompleks yang memiliki beberapa subsistem. Sejauhmanakah koordinasi diantara berbagai subsistem dalam program dilakukan, merupakan pertanyaan penting yang harus dijawab dalam mengevaluasi proses program.

Kinerja proses kegiatan Program Anti Kemiskinan (Anti Poverty Program) Bidang Pertanian mulai tahap persiapan, pertanggungjawaban, pelestarian program, pemantauan dan pelaporan, pengawasan dan pengendalian secara umum sudah sesuai dengan Pedoman Umum yang ada. Namun ada beberapa tahapan yang masih kurang optimal dalam pelaksanaannya antara lain tahap perencanaan, pelaksanaan dan pengembangan. Tahap perencanaan berkaitan dengan pelaksanaan Musdes (Musdes) perencanaan. Untuk Musyawarah Desa perencanaan khususnya kegiatan yang didanai melalui APBD Provinsi Jawa Timur pelaksanaannya kurang optimal karena paket bantuan sarana dan prasarana produksi pertanian sudah ditentukan dari Dinas Pertanian Provinsi Jawa Timur. Kondisi ini mengakibatkan realisasi bantuan sarana dan prasarana produksi pertanian tidak sesuai dengan jadwal yang telah ditentukan (pada saat awal musim tanam).

Pada tahap pelaksanaan dan pengembangan Program Anti Kemiskinan (Anti Poverty Program) Bidang Pertanian, peran Pokmas dinilai biasa saja. Peran Pokmas dalam proses pengambilan keputusan sekitar 33,56\%, pelaksanaan $37,10 \%$ dan tahap pengembangan program 36,42 \%. Hal tersebut disebabkan anggota Pokmas merasa tidak memiliki kemampuan untuk terlibat dalam berbagai kegiatan, baik karena faktor pendidikan maupun pengetahuan. Keadaan ini bisa menjadi faktor penyebab kemiskinan, sebagai akibat adanya keterbatasan sumberdaya manusia atau 
sumberdaya lain, sehingga peluang produktif relatif kecil dan tidak dapat berperan dalam pembangunan.

Sesuai pendapat Effendi [15], secara ekonomi kemiskinan adalah kekurangan sumber daya yang dapat digunakan untuk meningkatkan kesejahteraan. Secara sosial kemiskinan diartikan kekurangan jaringan sosial dan struktur untuk mendapatkan kesempatan-kesempatan meningkatkan produktivitas. Sedangkan secara politik kemiskinan diartikan kekurangan akses terhadap kekuasaan.

\section{Kinerja Output}

Menurut Mahmudi [13], Output, adalah hasil langsung dari suatu proses. Output merupakan sesuatu yang terjadi akibat proses tertentu dengan menggunakan masukan/input yang telah ditetapkan. Indikator output dijadikan landasan untuk menilai kemajuan suatu aktivitas atau tolok ukur yang dikaitkan dengan sasaransasaran yang telah ditetapkan dengan baik dan terukur. Indikator Output Program Anti Kemiskinan (Anti Poverty Program) Bidang Pertanian terdiri dari jumlah keluarga miskin yang tertangani.

Berdasarkan pendataan Program Perlindungan Sosial PPLS BPS Tahun 2011, jumlah Gakin di wilayah obyek penelitian sebanyak 1.463. Adanya kegiatan Program Anti Kemiskinan (Anti Poverty Program) Bidang Pertanian, secara keseluruhan jumlah Gakin di wilayah obyek penelitian yang tertangani sebanyak 593 atau sebesar 40,53\%.
Sejalan dengan pendapat Friedmann [4], bahwa untuk memahami lebih jauh persoalan kemiskinan, salah satu kajian kemiskinan berhubungan dengan target population (populasi sasaran) yaitu kelompok orang tertentu yang dijadikan sebagai objek, kebijakan serta program pemerintah, berupa rumah tangga yang dikepalai perempuan, anak-anak, buruh tani yang tak punya lahan, petani tradisional kecil, korban perang dan wabah, serta penghuni kampung kumuh perkotaan. Pada Program Anti Kemisinan (Anti Poverty Program) Bidang Pertanian yang menjadi target population adalah Kelompok Masyarakat (Pokmas) Rumah Tangga Miskin berdasarkan Data PPLS 2008 dan atau PPLS 2011 (by name by address) yang berpotensi untuk dikembangkan melalui pemberdayaan usaha ekonomi produktif berbasis cluster.

\section{Kinerja Outcome}

Outcome (hasil) adalah segala sesuatu yang mencerminkan berfungsinya keluaran kegiatan pada jangka menengah. Outcome merupakan ukuran seberapa jauh setiap produk jasa dapat memenuhi kebutuhan dan harapan masyarakat [16]. Indikator kinerja outcome merupakan ukuran kinerja dari program dalam memenuhi sasarannya. Pencapaian sasaran dapat ditentukan dalam satu tahun anggaran, beberapa tahun anggaran atau periode pemerintahan. Pada kinerja outcome yang digunakan dalam penilaian kinerja adalah sebagai berikut:

Tabel 2. Prosentase Peningkatan Pendapatan Pokmas Sebelum Terbantu dan Sesudah Terbantu Program Anti Kemiskinan (Anti Poverty Program) Bidang Pertanian

\begin{tabular}{|c|c|c|c|c|c|c|}
\hline \multirow[t]{2}{*}{ No. } & \multirow[t]{2}{*}{ Desa } & \multirow[t]{2}{*}{ Nama Pokmas } & \multirow[t]{2}{*}{$\begin{array}{l}\text { Jumlah } \\
\text { Anggota }\end{array}$} & \multicolumn{2}{|c|}{$\begin{array}{c}\text { Rata-rata Pendapatan Pokmas } \\
\text { ( RP.) }\end{array}$} & \multirow{2}{*}{$\begin{array}{c}\text { Prosentase } \\
\text { Peningkatan } \\
(\%)\end{array}$} \\
\hline & & & & Sebelum & Sesudah & \\
\hline \multirow[t]{2}{*}{1.} & Ngadipuro & Mandiri & 50 & 602.600 & 714.500 & 18,57 \\
\hline & & Sejahtera & 50 & 590.100 & 693.150 & 17,46 \\
\hline \multirow[t]{2}{*}{2.} & Bunut & Bangun Tani & 60 & 740.800 & 861.500 & 16,29 \\
\hline & & Tani Mulyo & 60 & 729.500 & 853.300 & 16,97 \\
\hline \multirow[t]{2}{*}{3.} & Patihan & Tunas Karya & 60 & 563.300 & 687.300 & 22,01 \\
\hline & & Sejahtera Mandiri & 60 & 496.600 & 616.000 & 24,04 \\
\hline 4. & Banjar & Tani Maju & 53 & 1.462 .250 & 1.579 .000 & 7,98 \\
\hline \multirow[t]{2}{*}{5} & Kedungharjo & Mekar Jaya & 50 & 646.000 & 768.000 & 18,89 \\
\hline & & Makmur Jaya & 50 & 667.000 & 794.000 & 19,04 \\
\hline 6. & Kujung & Ayem Tani & 50 & 636.000 & 728.700 & 14,58 \\
\hline \multirow[t]{3}{*}{7.} & Tegalsari & Tanjungsari & 50 & 635.000 & 729.100 & 14,82 \\
\hline & \multicolumn{2}{|c|}{$\mathrm{Jumlah}$} & 593 & 7.769 .150 & 9.024 .550 & 16,16 \\
\hline & \multicolumn{2}{|c|}{ Rata-rata } & & 706.286 & 820.400 & 16,16 \\
\hline
\end{tabular}

Sumber : Laporan Akhir Program Anti Kemiskinan Kabupaten Tuban Tahun 2012 [12]

a. Penyerapan Tenaga Kerja
Program Anti Kemiskinan (Anti Poverty Program) Bidang Pertanian dapat menyerap 
tenaga kerja produktif unskill sebagai buruh tani sebanyak 625 orang di 11 Pokmas dan 7 Desa sasaran. Masih tingginya peran sektor pertanian dalam penyerapan tenaga kerja yang ada saat ini, menggambarkan tingkat pencapaian suatu sasaran atau tujuan yang ditetapkan yaitu mendorong terciptanya wirausaha baru.

Hal tersebut didukung dengan pendapat Mahmudi [13] Outcome adalah hasil yang dicapai dari suatu program atau aktivitas dibandingkan dengan hasil yang diharapkan. Outcome merupakan dampak program atau aktivitas terhadap masyarakat.

Pendapat yang sama disampaikan oleh Mahsun [11], indikator outcome adalah segala sesuatu yang mencerminkan berfungsinya keluaran kegiatan pada jangka menengah (efek langsung). Outcome menggambarkan tingkat pencapaian atas hasil lebih tinggi yang mungkin mencakup kepentingan banyak pihak. Melihat tingginya peran sektor pertanian dalam menyerap tenaga kerja, maka pemerintah perlu menempatkan sektor ini sebagai sektor penting untuk dikembangkan bersama dengan sektor lainnya.

\section{b. Prosentase Peningkatan Pendapatan Anggota Pokmas Sebelum dan Sesudah Terbantu}

Secara kualitas Program Anti Kemiskinan (Anti Poverty Program) Bidang Pertanian, dapat meningkatkan pendapatan anggota Pokmas dan penyerapan tenaga kerja. Secara keseluruhan pendapatan Pokmas sebelum terbantu Program Anti Kemiskinan (Anti Poverty Program) Bidang Pertanian rata-rata Rp. 706.286,-. Kemudian setelah menerima program rata-rata pendapatan meningkat menjadi Rp. 820.400,- atau mengalami kenaikan kenaikan rata-rata sebesar 16,16\%, sebagaimana terdapat dalam Tabel 2.

Kinerja Outcome Program Anti Kemiskinan (Anti Poverty Program) Bidang Pertanian dapat membuka peluang penyerapan tenaga kerja bagi Pokmas Gakin sebanyak 625 orang dan dapat meningkatkan pendapatan Pokmas rata-rata sebesar $16,16 \%$. Akan tetapi program tersebut masih belum dapat berperan dalam pengentasan kemiskinan. Hal ini disebabkan pendanaan yang diberikan masih terbatas sehingga jumlah penduduk yang menjadi sasaran program juga terbatas.

\section{KESIMPULAN DAN SARAN Kesimpulan}

Program Anti Kemiskinan (Anti Poverty Program) Bidang Pertanian di Kabupaten Tuban pelaksanaannya belum berjalan secara maksimal. Rata-rata pendidikan anggota Pokmas sebagai pengelola program sangat rendah, dimana hampir 81,28 \% sampai dengan lulusan SD. Hal ini menyebabkan Pokmas kurang aktif dalam proses perencanaan, pengambilan keputusan, pelaksanaan dan pengembangan program. Selain itu sebanyak 71,02 \% lahan pertanian yang dimiliki oleh Pokmas kurang dari 0,5 hektar sehingga usaha pertanian masih banyak didominasi oleh usaha skala kecil dengan modal terbatas.

Untuk pelaksanaan bantuan melalui APBD Provinsi Jawa Timur masih bersifat top down karena paket bantuan sudah ditentukan oleh SKPD yang membidangi. Sedangkan kegiatan yang didanai melalui APBD Kabupaten Tuban dinilai lebih optimal karena realisasi bantuan disalurkan secara langsung kepada Kelompok Masyarakat (Pokmas) melalui cash transfer ke masing-masing rekening pengurus sesuai mekanisme APBD Kabupaten. Akan tetapi pendanaan yang dibantukan masih relatif sedikit dibandingkan dengan jumlah Gakin di wilayah penelitian sehingga hasilnya kurang maksimal.

Secara kualitas, Program Anti Kemiskinan (Anti Poverty Program) Bidang Pertanian dapat membantu Pokmas Gakin sebanyak 593 Gakin dari 1.463 Gakin atau sebesar 40,53\% yang tersebar di 7 Desa, penyerapan tenaga kerja produktif unskill sebagai buruh tani sebanyak 625 orang dan prosentase peningkatan pendapatan Pokmas rata-rata sebesar $16,16 \%$.

\section{Saran}

1. Meningkatkan kapasitas sumberdaya Pokmas melalui kegiatan pelatihan

2. Pemerintah Kabupaten Tuban perlu mengalokasikan dana pendamping yang cukup besar

3. Mekanisme penyaluran dana Pengelolaan Program Anti Kemiskinan (Anti Poverty Program) Bidang Pertanian dari APBD Provinsi Jawa Timur, hendaknya melalui Bantuan Keuangan Pokmas sesuai peraturan yang berlaku

4. Mitra Usaha perlu difasilitasi dan diverifikasi agar mampu membeli hasil produk anggota

5. Kelembagaan Pokmas agar diperkuat.

\section{UCAPAN TERIMA KASIH}

Ucapan terima kasih Saya sampaikan kepada Bupati Tuban, Kepala BAPPEDA Kabupaten 
Tuban serta semua pihak yang telah membantu penelitian ini.

\section{DAFTAR PUSTAKA}

[1]. Roesminingsih dan Eman Ramelan. 2008. Menakar Keefektifan Program JPES di Provinsi Jawa Timur. Catatan Hasil Evaluasi dan Monitoring di Lapangan. Biro Adminsitrasi Pembangunan Provinsi Jawa Timur.

[2]. Badan Pusat Statistik (BPS) Provinsi Jawa Timur. 2012. Profil Kemiskinan di Jawa Timur Maret 2012.

[3]. Badan Pusat Statistik (BPS) dan BAPPEDA Kabupaten Tuban, 2012. Kabupaten Tuban Dalam Angka Tahun 2011.

[4]. Friedman, John, 1992. "Empowerment : The Politics of Alternative Development." Blackwell Book, Cambridge Mass.

[5]. BAPPEDA Provinsi Jawa Timur, 2013. Pedoman Umum Program Anti Kemiskinan (Anti Poverty Program/APP) Tahun 2013.

[6]. Kosasih, Husein 2004. TeknikPengukuran Dan Evaluasi Kinerja Satuan Organisasi/Kerja di Lingkungan Departemen Agama, Modul Diklat AKIP/LAKIP. Badan Litbang dan Diklat Keagamaan Pusdiklat Administrasi, Departemen Agama RI. Jakarta.

[7]. Lembaga Administrasi Negara, 2004. Modul Sistem Akuntabilitas Kinerja Instansi Pemerintah, Edisi Kedua, Jakarta.

[8]. Moleong, J. Lexy, 2000. Metodologi Penelitian Kualitatif. Penerbit PT. Remaja Rosdakarya. Bandung.

[9]. Miles, Matthew B, dan A Michael Huberman, 1992. Analisis Data Kualitatif. Diterjemahkan oleh Tjejep Rohendi Rohidi. UIP. Jakarta.

[10]. Shafritz, J.M. dan Russel, E.W., 1997, Introducing Public Administration, New York: Addison Wesley Educational Publisher.

[11]. Mahsun, Mohammad. 2006. Pengukuran Kinerja Sektor Publik.Penerbit BPFE. Yogyakarta.

[12]. BAPPEDA Kabupaten Tuban, 2012. Laporan Akhir Program Anti Kemiskinan Kabupaten Tuban Tahun 2012.

[13]. Mahmudi, 2010. Manajemen Kinerja Sektor Publik. Edisi Kedua. UPP STIM YKPN. Yogyakarta.

[14]. Makmur, Moch., 2010. Bahan Kuliah Monitoring dan Evaluasi. FIA UB. Malang.

[15]. Efendi, Tadjuddin Noer, 1993. Sumber Daya Manusia, Peluang Kerja dan
Kemiskinan. PT Tiara Wacana Yogyakarta.

[16]. Lembaga Administrasi Negara, 2003. SK Kepala LAN Nomor : 239/1X/6/8/2003. Perbaikan Pedoman Penyusunan Pelaporan Akuntabilitas Kinerja Instansi Pemerintah. Jakarta. 